\title{
Opening Address: International Conference of Muslim Social Scientists
}

\section{Tahā J. al Alwānì}

The year which has just ended has presented the Muslim world with a major challenge: the bipolar world order which provided some kind of balance between the East and the West disintegrated and was replaced by a unipolar one. How will this affect us?

The new world order is an order controlled by a single superpower which has its own philosophy, thought, and culture. If we look closely, it seems that its philosophy stands on a collection of what appears to be mutually opposed dualities which both necessitate the various elements of conflict and make all attempts to end the resulting polarization and conflict futile. But the recent demise of the opposite pole and the end of the Cold War does not mean that the world is about to witness a period of peace, tranquility, and security in the shade of this so-called new world order. Rather, the inherently belligerent nature of this entirely Western-controlled civilization precludes such a development, for such an order requires an opponent, either real or imagined. In other words, if one is not readily available it will have to be created, so that the fight can be carried on elsewhere. While many are now saying that the nature of the conflict may shift from military to economic power, this does not automatically mean that positive developments will occur or that the world can expect true and constant security, tranquility, or peace from this civilization.

It is thus all the more disconcerting that the Islamic world finds itself in a state of unpreparedness and disarray unprecedented in all of its long history, and that the collapse of the Soviet Union, the other Western pole, leaves the role of adversary to the Islamic world. All of this suggests that the Islamic world, which is now infirm, divided, and unable to protect its own resources, will be faced with the prospect of becoming a battleground over the course of the next few decades.

It is therefore essential that Muslim scholars, thinkers, research institutes, universities, and enlightened political elites undertake the responsibility of ensuring that the Islamic world passes through this coming period of crisis success-

Tāhā J. al 'Alwānī is President of the International Institute of Islamic Thought in Herndon, Virginia. This paper was presented by Hakim Rashid at the First International Conference of Muslim Social Scientists, held in cooperation with Hamdard University, Karachi, Pakistan, during January 2-7, 1992. 
fully, that it somehow avoid the possibility of facing ultimate collapse and disintegration, God forbid! When we, as scholars and thinkers, consider solutions to our crisis, we realize that it is impossible to think that such a solution would only solve our problems or those of a specific part of the Islamic world. Rather, the solution must be comprehensive, one which addresses the global problems now facing humanity, so that it solves not only our problems but those of humanity as well.

The comprehensive solution of which I speak is this: that the ummah present both to its own members and to humanity at large an intellectual and ideational alternative capable of saving humanity from the dangers which threaten it; one which can deliver contemporary civilization from its present crisis; one which can bring about a truly new world order based on true peace, eternal security, and stability; and one in which real values and morals lead humanity to the ultimate good and to the true religion. This, of course, is something that will never come about without Islam, for God has said: "O you who have faith, come to full submission to God, and follow not the ways of Satan. . .Verily he is to you a declared enemy" (Quran 2:208).

Here, full submission to God is conditional upon our undertaking a new reading of the book of Allah and acquiring a deeper understanding of the Sunnah and the sirah of the Prophet of God, upon him be peace, through a more intense and analytical study of the sources of guidance. A new methodology for understanding and interpreting these sources needs to be developed, one capable of absorbing a multiplicity of cultures and a diversity of civilizations, of combining the interests and aspirations of the world's many varied peoples, and of bringing them together as the subjects of One Lord and as the sons and daughters of one common ancestor.

If Muslims continue to present Islam in its traditional understanding or interpretation, Islam will benefit neither the Muslims nor anyone else. Rather, Muslim scholars and thinkers, especially Muslim social scientists, need to unite in the cause of Allah and then identify and give serious consideration to their real responsibilities to the ummah and to humanity. Their role in reinterpreting Islam, in presenting it intelligently, and in applying it to the problems of the menaced and unsettled contemporary world needs to be thought out.

The collapse of the communist bloc should not be viewed as meaning that the other side of the coin (i.e., the liberal, capitalist Western civilization) is automatically out of danger. Rather the opposite is true, for the possibility of the liberal, capitalist trend represented by American civilization's intellectual and cultural collapse has never been greater. This is due to the inability of that civilization's intelligentsia to provide the solutions which will deliver it from its present social crises, not to mention the myriad crises that loom darkly on its horizon.

At the present time, then, great danger threatens all of humanity. It is 
therefore essential that Muslim scholars and thinkers increase and intensify their efforts to discover a new and relevant methodology for understanding the Qur'an, one which will allow its eternal message to be presented to humanity as a reasonable alternative. This is our role and our responsibility atthe present time. May Allah make this conference a true beginning towards the serious work I have outlined here. 